\title{
Armed group transition from rebel to government
}

William Avis

University of Birmingham

18/10/2021

\section{Question}

What has been learnt about how armed groups manage the transition from rebel to government?

\section{Contents}
1. Summary
2. Armed Groups Post-Conflict Transitions
3. Case Studies
4. References

The K4D helpdesk service provides brief summaries of current research, evidence, and lessons learned. Helpdesk reports are not rigorous or systematic reviews; they are intended to provide an introduction to the most important evidence related to a research question. They draw on a rapid deskbased review of published literature and consultation with subject specialists.

Helpdesk reports are commissioned by the UK Foreign, Commonwealth, \& Development Office and other Government departments, but the views and opinions expressed do not necessarily reflect those of FCDO, the UK Government, K4D or any other contributing organisation. For further information, please contact helpdesk@k4d.info. 


\section{Summary}

Governments and political parties with an armed history are not unusual, yet how these groups function during and after the transition from conflict has largely been ignored by the existing literature. Many former armed groups have assumed power in a variety of contexts. Whilst this process is often associated with brokered peace agreements that encourage former combatants to transform into political parties, mobilise voters, and ultimately stand for elections, this is not always the case. What is less clearly understood is how war termination by insurgent victory shapes patterns of post-war politics. This rapid literature review collates available evidence of transitions made by armed groups to government. The literature collated presents a mixed picture, with transitions mediated by an array of contextual factors that are location and group specific. Case studies are drawn from a range of contexts where armed groups have assumed some influence over government (these include those via negotiated settlement, victory and in contexts of ongoing protracted conflict). The review provides a series of readings and case studies that are of use in understanding how armed groups may transition in "post-conflict" settings. Case studies are drawn from a range of contexts including Uganda, Ethiopia, Libya, Burundi, East Timor, Aceh, Colombia, Palestine, Lebanon, Mozambique, Angola and Rwanda.

The evidence suggests that in tracking how political legacies established during wartime can affect armed groups' approaches to politics after war, it is important to understand the multilayered relationships these actors establish during conflict. A successful insurgent armed group is simultaneously a political party, military organisation, and a business organisation, and this 'triple feature' is essential to understanding protracted armed conflict as well as transitions in the 'post-conflict' period. Commentators have asserted that the politics of war time (sometimes referred to as 'rebel politics') must address the same sets of challenges as more traditional forms of governance, except in a context where violence and predation are rewarded and consequently more pronounced.

A challenge identified in the literature is to identify the factors that explain how ex-combatants decide to mobilise and organise and how, when in a position to govern, they decide to relate to their former members. Moving beyond the instrumentalist notion of describing ex-combatants role in the governance of post-conflict societies, the relationship is not straightforward. As several studies show, demobilisation can be a complex process, as ex-combatants have high expectations of what their sacrifice and subsequent contribution to peace either via a settlement or victory will bring in the forms of rewards, elevated status and economic compensation. What is clear from the growing literature in this field is that both the legacies of armed group mobilisation as well as the nature of conflict endings (settlement versus victory) impact the transition process. Interlinked and crosscutting factors that influence transition may include:

- Origins of the combatants: The origins of political actors, often deeply affects their organisation, political culture, strategic behaviour and democratic capacity and participation in the (electoral) political game.

- Experience of administration: Insurgent groups engaged in protracted civil war often have direct experience administering liberated territory. When this is the case they may be more able to govern than others who lack this experience.

- Interdependency between elites, combatants and civilian support networks: Wartime mobilisation can create strong and lasting ties of inter-dependency between 
leadership elites of the rebel group and ex-combatants and their civilian support networks - these interdependencies can both support and hinder transitions.

- Strength of networks of (former combatants): Similarly, another area of concern is the strength of networks of former combatants. Peacebuilding and reintegration policies often try to break such networks and disconnect individuals from each other. How important these networks are for the functioning of these groups in post-conflict settings requires further investigation.

- Wartime legacies: An important factor shaping the rebel-to-political transition of armed movements in post-conflict settings pertains to the political identity these groups develop in wartime. This political identity is itself a multi-dimensional concept shaped not only by the political ideology, practices and institutions established by the rebel organisation, but also by the relationship with the state and its political institutions.

- Nature of war termination: The existing literature on the links between different types of war termination and post-war politics has inconsistent findings. Some authors suggest victory can lead to democratisation, others challenge this finding.

- Initial legitimacy from victory: Victorious rebels are more likely to derive legitimacy from defeating the old order and ending the violence.

- Power consolidation rather than power-sharing: victorious insurgents often focus on consolidating and expanding their political power, incorporating new constituencies, and building upon their pre-existing wartime structures of command and control.

\section{Armed Groups Post-Conflict Transitions}

Governments and political parties with an armed history are not unusual, yet how these groups function during and after the transition from conflict has largely been ignored in the existent literature (Sindre \& Söderström, 2016). Sindre and Söderström (2016) continue that in recent decades, many former armed groups have assumed power in a variety of contexts. Whilst this process is often associated with brokered peace agreements that encourage former combatants to transform into political parties, mobilise voters, and ultimately stand for elections, this is not always the case. What is less clearly understood is how war termination by insurgent victory shapes patterns of post-war politics. While the percentage of civil wars that end in negotiations grew dramatically after the end of the Cold War, overall in the period between 1940-2000, a significant percentage (40\%) still ended in victory (Toft, 2010: 6). In turn, Söderberg, Kovacs and Svensson (2012) argue that armed conflicts are increasingly ending in situations where rebels are labelled as terrorists with whom negotiations are presumed to be impossible. Questions that emerge from the literature regarding non-state actors and their role in post-conflict governance include (Lyons 2016a; 2016; Sindre \& Söderström; 2016):

- Does the culture of non-state armed groups change over time?

- What allows or determines whether parties to conflict break patterns of behaviour that delivered victory and adopt more democratic internal workings or not?

- Does the nature of the conflict matter (Lyons 2016)?

- Does the nature of conflict-ending matter (Lyons 2016a)?

- Do insurgent victories produce less inclusive and more authoritarian governance mechanisms than those emerging from negotiated settlements? 
- What influence does the foundational ideology or political aspirations of armed movements have on transitions?

Armed groups are thus not only the central protagonists of contemporary war-making; but they are also increasingly shaping both wartime and peacetime political orders (Harbom et al. 2006).

In tracking how wartime political legacies during conflict can affect armed groups' approaches to politics after war, it is important to understand the multi-layered relationships established during conflict with the state and its political institutions. As Staniland (2012) comments, the relationship between an armed group and the government of the state from which they operate can vary from one of open conflict and confrontation, to one of sporadic clashes and latent conflict, to de facto détente and forced yet separate co-existence, to fully fledged cooperation or mutual dependence or shared sovereignty (with or without conflict) (Staniland, 2012).

Adding further complexity, analysing the state-rebel political interactions requires a better understanding of the dense network of relations these groups establish with their environment in providing social services and governance. Unsurprisingly, these governance networks can have an impact on the armed group's role and status both in wartime as well as in a post-conflict setting (Börzel, 2010).

Elaborating on this point, Collier et al. (2003), have noted that a successful insurgent armed group is simultaneously a political party, military organisation, and a business organisation and that this 'triple feature' is essential to understanding protracted armed conflict (Collier et al., 2003: 56). Numerous authors have asserted that the politics of war time (sometimes referred to as 'rebel politics') must address the same sets of challenges as more traditional forms of governance, except in a context where violence and predation are rewarded and consequently more pronounced. In this formulation, civil war is a form of contentious politics that requires a particular type of organisation, the insurgent group (Collier et al., 2003).

Political organisations in the context of civil wars thus respond to a specific set of incentives and opportunities. The presence of protracted violence and the breakdown of the state's monopoly on the use of force lead to specific forms of governance. Governance in the form of norms, expectations, and patterns of behaviour shape perceptions of what is politically possible and creates the context in which strategies are considered and adopted (Sindre \& Söderström, 2016).

Further to this, protracted civil wars require institutions with highly developed capacities and structures to mobilise supporters and provision armed forces. Civil wars may be initiated by grievance or frustration or greed but to become protracted and sustained for decades requires institutions that respond to the incentives and opportunities of violence, mobilise and coordinate large numbers of fighters and supporters, and overcome the collective action problem (Lyons, 2016). Civil wars produce wartime governance and wartime institutions and this context in turn reinforces strategies of violence and political actors that are able to manage the risks and seize the opportunities of war (Sindre \& Söderström, 2016).

Following on from the above, as Sindre \& Söderström (2016) comment, the challenge is to identify the factors that explain how ex-combatants decide to mobilise and organise and how, when in a position to govern, they decide to relate to their former members. Moving beyond a mere description of ex-combatants role in the governance of post-conflict societies, the relationship is not straightforward. As several studies show, demobilisation can be a complex 
process, when a group has high expectations of what their sacrifice and subsequent contribution to peace either via a settlement or victory will bring in the forms of rewards, elevated status and economic compensation. What is clear from the growing literature in this field is that both the legacies of armed group mobilisation as well as the nature of conflict endings (settlement versus victory) impact the transition process - a number of factors that influence this transition are briefly explored below.

\section{Origins of the combatants}

The origins of political actors, often deeply affect their organisation, political culture, strategic behaviour and democratic capacity and participation in the (electoral) political game (Lyons, 2016; 2016a; 2016b).

\section{Experience of administration}

Insurgent groups engaged in protracted civil war often have direct experience administering liberated territory (Lyons, 2016). In this way rebels, and particularly victorious rebels, have experience in performing functions of political administration. During civil war, military structures play roles that political parties are expected to play in peacetime. Victorious insurgent groups often carry these models and precedents of military governance into the post-war political arena (Wittig, 2016; Sindrea, 2016). The necessity to administer newly acquired territory provides incentives to develop cadres with skills to mobilise civilians under the difficult circumstances of violence and insecurity with the goal of supporting a military strategy. The institutions established by the insurgent organisations in liberated territory are designed in ways to facilitate recruitment, allow access to recruitment, and to monitor for the penetration of countervailing sources of authority (Arjona, 2014). In some cases, insurgent groups do more than control violence but seek to provide some level of public goods - what has been referred to by Arjona (2014) as a 'rebelocracy'. These precedents shape post-war governance as successful military administrators are converted (at least formally) into peacetime governors.

\section{Interdependency between elites, combatants and civilian support networks}

Wartime mobilisation can create strong and lasting ties of inter-dependency between leadership of the rebel group and ex-combatants and civilian support networks. Putting emphasis on the degree of institutionalisation, Sindre (2016) demonstrates the saliency of path dependency between wartime organisational structure and the degree and mode of inclusion of excombatants in decision making post-conflict. Although organised according to strict hierarchical command structures, in matters concerning governance, midlevel regional commanders may retain a significant amount of autonomy. Such organisational trajectories have direct impact on leader-member relationships when rebel groups reorganise as governing power.

As rebel groups transform in the post-conflict period, one might also expect a transformation of these incentives. Here, it is useful to relate the organisational and mobilisational legacies of the armed movement, in particular:

- How were members mobilised and integrated into the group during war?

- To what extent are the rebel group's wartime organisational characteristics? 
- Were the group's mobilisational strategies an asset, or not?

Analyses of rebel group mobilisation have highlighted the significance of mobilisational incentives that rebel groups rely on to build coherent organisations during war, distinguishing between selective, market-based incentives or ideational incentives (Weinstein 2007).

In general, it is expected that groups that rely on ideology also have more loyal and committed supporters, while those that also depend on providing selective incentives, primarily material goods, need to continue to provide such provisions in order to retain their loyalty (Weinstein 2007). The pressures of protracted conflict forge relationships based on interdependence if not trust among leaders and between leaders and the rank and file. How these interdependencies evolve over short-, medium- and long-term time frames is subject to much debate and influenced by contextual factors.

\section{Strength of networks of (former combatants)}

Another area of concern is the strength of networks of former combatants. Peacebuilding and reintegration policies often try to break such networks and disconnect individuals from each other. How important these networks are for the functioning of these groups in post-conflict settings requires further investigation e.g. in the case of Colombia (Söderström, 2016).

\section{Wartime legacies}

An important factor shaping the rebel-to-political transition of armed movements in post-conflict settings pertains to the political identity these groups develop in wartime. This political identity is itself a multi-dimensional concept shaped not only by the political ideology, practices and institutions established by the rebel organisation, but also by the relationship with the state and its political institutions. Far from functioning in a vacuum or isolated, rebel groups, especially when operating as alternative providers of governance, build multi-layered networks of relations with the state, the pre-existing traditional institutions of society as well as with other domestic and international political actors (Berti, 2016).

The legacies of how insurgents organise themselves as proto-parties during the time of armed struggle shape how post-war parties and political order are structured. According to Lyons (2016) rebels that won after sustained conflicts fought in confined territories with experience in wartime administration of liberated territory transformed into strong authoritarian ruling parties. These transformations succeeded in ending the wars and creating stability but did little to advance democratisation. In Uganda, there was a period of 'no-party' democracy 1990s and in Ethiopia there were a series of non-competitive elections that resulted in the ruling party winning by majorities of over $90 \%$. Each regarded dissent as illegitimate and used state power to repress local media and civil society (Lyons 2016).

In other cases, insurgents that replaced incumbent regimes after very short wars fought over broad territory with significant help from external powers resulted in post-war parties that lacked coherent leadership or experience in governing e.g. Libya. These transformations succeeded in replacing brutal incumbents like Mobutu and Qaddafi but failed to sustain the peace or even consolidate control over the state's territory. 


\section{Nature of war termination}

The existing literature on the links between different types of war termination and post-war politics has inconsistent findings:

- Toft (2010) argues that civil wars that end in rebel victory are more inclined to produce democratic outcomes. This is because victorious insurgents have both the military capability to penalise spoilers and the incentives to govern justly in order to gain legitimacy from domestic constituencies and the international community. Toft (2010: 60) argues that a 'victor's peace' will lead to stronger institutions which in turn lead to 'a more stable, and perhaps more democratic, system of government.'

- Fortna and Huang (2012), however, found little support in the quantitative data for the hypothesis that military victories - including insurgent victories - improve the prospects for democratisation. Lyons (2016) argues that the legacies of the war and dynamics of the war-to-peace process following rebel victory make authoritarian regimes more likely.

- Söderberg Kovacs and Svenson (2012) also critique Tofts' (2010) position commenting that conflict resolution represents a peaceful way of managing and resolving armed conflicts. This is in sharp contrast to war termination strategies aiming for military victory where the use of force is the main tool used to accomplish peace. Negotiated settlements are seen to lead to more stable and durable peace than military victories.

\section{Ideology versus material interests}

Another concern often raised about helping armed groups transform into political parties relates to their lack of politics (Sindre \& Söderström, 2016). As many armed groups are seen to be driven by other things (material gain for example) than legitimate political claims and visions, concerns are raised about whether they will contribute with a serious political agenda when they enter electoral politics. Della Porta's (2013) comparative work on clandestine political violence emphasises the specific nature of solidarity that arises from underground politics. Clandestine organisations tend to be particularly centralised, hierarchical, and compartmentalised and become more so as repression and violence escalate. A coterie of linked leaders and high levels of solidarity forged in wartime facilitate the transition from a rebel movement to a strong authoritarian political party.

In general, it is expected that groups that rely on ideology also have more loyal and committed supporters, while those that also depend on providing selective incentives, primarily material goods, need to continue to provide such provisions in order to retain their loyalty (Weinstein 2007).

\section{Initial legitimacy from victory}

Victorious rebels are more likely to derive legitimacy from defeating the old order and ending the violence. Rebels who fight to stalemate and accept negotiations can claim a role in forcing a transition, but those claims are more ambivalent and contingent than claims of unilateral victory. According to Lyons (2016b), war-weary publics often appreciate parties that can credibly promise security, and there is some survey evidence to show that exposure to protracted conflict leads a population to be more willing to accept authoritarian leaders 


\title{
Power consolidation rather than power sharing
}

Lyons (2016b) comments that in contrast to cases of negotiated settlements, vanquished incumbents are not likely to play important post-conflict roles in cases of insurgent victory. Rather than struggling with power-sharing or the integration of rebel forces into the national military, victorious insurgents can focus on consolidating and expanding their political power, incorporating new constituencies, and building upon their pre-existing wartime structures of command and control.

\section{Victorious rebels and post-war politics}

\author{
Lyons, T. (2016). Victorious rebels and postwar politics. Civil Wars. Volume 18. \\ https://doi.org/10.1080/13698249.2016.1205562
}

This paper examines cases of rebel victories in civil wars in Africa and traces the links between war duration, the extent of external intervention, and whether or not the war was fought in a compact area with the nature of the post-war political parties. It argues that protracted wars in confined territory with little external assistance have different organisational legacies than quick wars fought over expansive territory with significant international involvement. This paper argues that there are two models of post-war politics following insurgent victory.

- The first sees battle-hardened insurgents transform into strong, authoritarian parties that dominated post-war politics (e.g. Uganda and Ethiopia).

- The second is characterised by international intervention that significantly undermined the incumbent and that saw 'accidental victors' struggle to consolidate power and overcome rivals (e.g. Libya).

Lyons (2016) comments that in some cases, notably Uganda and Ethiopia, prolonged civil wars fought in relatively compact areas and without significant external involvement created rebels with strong, coherent leadership and experiences in administering liberated territory. These legacies then supported the transformation of the victorious insurgents into the strong authoritarian ruling parties.

While strong coherent rebel movements are more likely to win civil wars, in a number of cases disorganised insurgent groups have replaced incumbent regimes, often with significant external assistance. In the Democratic Republic of Congo (DRC) and Libya, for example, short wars fought over large areas with significant international involvement resulted in weak, deeply divided insurgent movements that took control of the capital as the incumbent regime collapsed. These victorious rebels lacked the time and opportunity to build coherent leadership and experience in wartime administration. 


\title{
Hybrid Political Orders
}

\author{
Anten, L. et al. (2012). The Political Economy of State-building in Situations of Fragility \\ and Conflict: from Analysis to Strategy. Clingendael Institute.
}

https://www.clingendael.org/sites/default/files/pdfs/20120100_cru_political_economy.pdf

According to the authors of this paper, the concept of hybridity is useful in bringing to the surface two key elements of governance:

- historically embedded disconnects between formal and informal institutions, and

- geographical areas that have been historically outside of state control.

In the DRC for example, the district of Ituri has been considered an ineffectual hybrid order, where large areas have consistently remained outside state control. The insecurity generated by violent conflict has led the population to rely on customary leaders for governance. The central state has supported recognition of those leaders through their position as collectivite chiefs. However, the informality characterising these sub-national entities has generated confusion, tensions and grey areas, with different ethnic groups contesting the boundaries of the chiefs' jurisdiction. The powers of these chiefs have been challenged, as they do not always translate into effective government services.

The authors continue that political hybridity assumes different connotations in the Guatemalan context. Here, it characterises the emergence of a new sort of state, in which intense transactions between officials, operating with private interests, and non-state parties, representing group interests, have become the dominant modus operandi. The lines between legitimate and criminal behaviour have been blurred, and the resulting 'informal accumulation of power' threatens efforts at state-building.

Another example used is that of Pakistan where the remoteness of certain areas has led to the establishment of localised traditional forms of governance. The absence of state institutions and the established presence of parallel structures and mechanisms negotiating access to and control of power at the local level created the ideal conditions for the emergence of hybrid institutional contexts. In the above examples, non-state institutions have carved out an operational space that is considered legitimate and effective, if only because the state has been perceived as either repressive or an absconding entity.

Another conclusion drawn from the examples above is that, where informal rules dominate governance, levels of institutionalisation are generally low, and people have little trust in formal institutions, in turn undermining the possibility of achieving political reform through institutional redesign.

\section{Case Studies}

\section{Rwanda}

Lyons, T. (2016b). The Importance of Winning: Victorious Insurgent Groups and Authoritarian Politics. Comparative Politics. Vol. 48, No. 2. 
https://www.jstor.org/stable/pdf/24886171.pdf?refreqid=excelsior\%3Afb5a563cbf28d170cc 73bc01067adcc1

This article argues that legacies of war and the imperatives of war-to-peace transitions following victory explain how victorious insurgent movements become strong authoritarian parties. It uses this mechanism to trace the process of transition in the cases of Uganda, Ethiopia (Lyons' views on these countries are presented in a following paper), and Rwanda.

Victorious rebellion and post-war authoritarian order are linked by a mechanism that includes the legacies of the war and the distinct imperatives of power consolidation after victory. Rather than building the conditions for more democratic regimes, path dependency will lead victorious insurgents to act as they did during the war and seize opportunities during the war-to-peace transition to consolidate their power. The mechanism that links war termination by rebel victory to a post-war political system dominated by a strong authoritarian party therefore consists of two main components:

- the legacies of the war that create path dependencies and;

- the specific dynamics of transitions following victory that create opportunities for power consolidation.

Lyons argues that four mechanisms link victorious rebels to strong authoritarian parties. Two link legacies of war with powerful military institutions' ability to re-create themselves as powerful political institutions.

1) the levels of solidarity and leadership coherence characteristic of successful insurgent groups; and

2) the precedents and organisational structures developed during wartime governance of liberated territory.

The third and fourth are processes that are inherent to the war-to-peace transition following rebel victory. These are

3) post-war legitimacy derived from military victory-"we rule because we won!"; and

4) the use of transitional processes, such as post-conflict elections, transitional justice, and demobilisation, as instruments of power consolidation.

The Rwandan Patriotic Front (RPF) has governed since it expelled the génocidaires in 1994 with the RPF evolving into a post-insurgent party defined by its strength and authoritarian nature. It is a mass-mobilising party with deep penetration into the countryside, not a narrowly based military or personalistic regime. It has won a series of largely uncompetitive elections since seizing power and has used the power of incumbency to intimidate opposition and limit political space. Paul Kagame, served as both leader of the insurgent movements and as post-war leader of ruling party and head of state.

Coherent leadership and solidarity: The RPF began with an already established set of seasoned military leaders who had fought together in Uganda. Rwigyema rose to deputy commander of the NRA before becoming commander of the RPA and Kagame served as head of military intelligence and was in the United States receiving training as an officer of the NRA when the civil war broke out 
Wartime governance: The RPF planned and organised its invasion of Rwanda for three years prior to crossing the border and anticipated a protracted civil war similar to the one many of them had experienced in Uganda. The RPF occupied a liberated zone along Rwanda's border with Uganda but did not control significant territory until 1993. The Rwandans had significant wartime experience fighting within the NRA in Uganda. Kagame headed the NRA's military intelligence, providing him with valuable experience in maintaining discipline and detecting defection. Refugee camps and the large Rwandan population within the diaspora provided additional opportunities to develop skills and institutions to manage civilians in support of the military campaign.

Post-conflict elections: A significant challenge faced by the RPF upon seizing power was that key national constituencies played little or no role in their respective insurgent movements. The civil wars had specific regional and ethnic concentrations, and many residents remained outside of the zones of violence. The winning rebels therefore needed to build institutional links to communities less directly involved in the armed struggle in order to govern as a national party.

The Tutsi-dominated RPF initially reached out to "moderate Hutus" so that it could position itself as a national party. By creating state-wide political parties, rebel movements with specific regional and ethnic origins could create new institutions that could claim to represent the whole of the population. Post-conflict elections provided the context for such institutional transformation. Elections following rebel victory, therefore, have little to do with determining who will rule, but rather perform key functions in power consolidation and in the creation of strong authoritarian parties. These polls are typically non-competitive.

\section{Uganda, Ethiopia and Libya}

Lyons, T. (2016). Victorious rebels and postwar politics. Civil Wars. Volume 18. https://doi.org/10.1080/13698249.2016.1205562

\section{Uganda}

The Ugandan Bush War, also known as the Luwero War, the Ugandan Civil War or the Resistance War, was a civil war fought in Uganda by the official Ugandan government and its armed wing, the Uganda National Liberation Army (UNLA), against a number of rebel groups, most importantly the National Resistance Army (NRA), from 1980 to 1986.

Lyons (2016) notes that the NRA organised the population in areas it controlled during the war through 'Resistance Committees' (RCs). The rebels 'generally' treated civilians in liberated territory well and the RCs were in some measure a form of village democracy reflecting local opinion and grievances. When military conditions contradicted local democracy, the NRA put military survival ahead of civilian protection. The RCs were a product of wartime conditions.

The models developed by the NRA to administer liberated territory became the basis for the NRA's local political structures after the war ended. When the NRA seized power in 1985, RCs were well established in western Uganda, where the rebels controlled territory, and were put in place elsewhere.

\section{Ethiopia}


Ethiopian Civil War was a civil war in Ethiopia and Eritrea, fought between the Ethiopian military junta communist governments and Ethio-Eritrean anti-government rebels from September 1974 to June 1991.

In northern Ethiopia, the Tigray People's Liberation Front (TPLF) saw itself as an army that would win by forging relationships with the people of Tigray. Following the Maoist model, the rebels deployed political cadres with its military units to insure discipline and organise regular selfcriticism sessions known as gimgema. The rebels created local councils known as baito ('peoples' council') to administer liberated zones. The baito provided a mechanism for top-down wartime governance and served to implement the TPLF's war policies.

During the mid-1980s famine, the Front had the capacity and local legitimacy to organise a movement of the population from Tigray to TPLF-controlled camps in Sudan. The movement had its own humanitarian wing, the Relief Society of Tigray (REST) that coordinated relief operations with international assistance, and the Tigray Development Association that raised significant resources in the diaspora. The insurgents played other state-like diplomatic roles, including having extensive (and often contentious) relationships with neighbouring insurgents in Eritrea as well as a range of international actors and organisations. The TPLF overthrew the dictatorship of the People's Democratic Republic of Ethiopia (PDRE) and established a new government in 1991 that ruled Ethiopia until it was ousted from power in the federal government in 2018.

\section{Libya}

The Second Libyan Civil War was a multi-sided civil war that lasted from 2014 to 2020 fought between different armed groups, mainly the House of Representatives and the Government of National Accord.

In Libya, after NATO air support prevented the rapid defeat of the opposition, the country became divided into an opposition controlled east and areas around Tripoli that remained under Qaddafi's control. Different armed actors seized control of different zones with no overarching political structure. Misrata's revolutionary brigades became particularly influential after withstanding a siege and the Zintan Military Council created an effective armed force based on Bedouin groups from the South. This decentralised war lacked an overarching organisational structure and the rebels struggled to establish a functioning government. Crosscutting microdynamics, local militias that controlled neighbourhoods, transnational Islamist networks and actors seeking to control key trade routes competed in a series of bloody, parochial conflicts.

\section{Burundi}

Wittig, K. (2016). Politics in the shadow of the gun: revisiting the literature on 'Rebel-toParty Transformations' through the case of Burundi, Civil Wars, 18:2. https://doi.org/10.1080/13698249.2016.1205561

The Burundian Civil War lasted from 1993 to 2005. The civil war was the result of longstanding ethnic divisions between the Hutu and the Tutsi ethnic groups. The conflict began following the first multi-party elections in the country since its independence from Belgium in 1962, and is seen as formally ending with the swearing-in of President Nkurunziza in 2005.

Burundi was long cited as a 'success story' for international liberal peacebuilding efforts by policymakers, diplomats, and academics alike. However, the enthusiasm for the country's post- 
accord transition has long neglected that National Council for the Defense of Democracy Forces for the Defense of Democracy (CNDD-FDD) increasingly returns to authoritarian practices and violence as a political tool to ensure its political hegemony. Latent political violence, including between CNDD-FDD and National Forces of Liberation (FNL), has replaced open armed conflict, but frequently escalates, especially around election time. While CNDD-FDD has become Burundi's current ruling party, FNL constitutes the major opposition force. Under CNDD-FDD's regime, Burundi has seen a constant authoritarian shift, coming to a head during the 2015 electoral crisis. Factions of CNDD-FDD and FNL have continued to use political violence.

\title{
East Timor and Aceh
}

\author{
Sindrea, G. (2016). In whose interests? Former rebel parties and excombatant interest \\ group mobilisation in Aceh and East Timor. Civil Wars. Volume 18. Issue 2. \\ https://doi.org/10.1080/13698249.2016.1205564
}

Sindrea comments that an important factor shaping rebel-to-party transformations and postconflict party governance pertains to how these groups relate to their former rank and file. While drawing on veterans of the war provides a stable source of support and organisational stability for the former rebel parties, ex-combatants may also pose challenges to such parties as they expect continued political influence, material rewards and social recognition for their contribution to the armed group. By identifying ex-combatants as a distinct interest group this argues that party-ex-combatant interaction directly shapes intra-party dynamics as well as policy formulation.

This article provides an exploration of Aceh and East Timor. The author notes that in both contexts, leaders of the liberation movements rose to political prominence in and are both challenged by former members of the armed movements. After having demobilised their troops, both the Free Aceh Movement (GAM) and the resistance movement in East Timor (Fretilin) have manifested themselves as major political parties since the conflicts ended, in 2005 and 2002, respectively. GAM's party, the Aceh Party, remains the largest party in the regional assembly; it has held the governorship since 2006 and controls a majority of posts as mayors and district heads across the province. In East Timor, Fretilin is the largest political party in the national assembly, but has failed to build broad enough coalitions to form government. Here, former resistance members divide their loyalties between several additional parties and groups.

\section{Aceh}

The insurgency in Aceh, officially designated the Rebellion in Aceh by the Indonesian government, was a conflict fought by the GAM between 1976 and 2005, with the goal of making the province of Aceh independent from Indonesia. The aftermath of a strong military offensive in 2003 and the 2004 Indian Ocean earthquake brought a peace agreement and an end to the insurgency.

In the case of GAM, a main challenge to the establishment of a political party was for the leadership, who had run the war from their exiled positions in Sweden, was the maintenance of organisational cohesiveness. Although formally GAM had in place a rather strict organisational hierarchy with powers divided between a government in exile, a political wing and a military wing (Tentara Nasional Aceh), on-the-ground authority was much more dispersed with special 
authorities awarded to regional commanders. Especially below the district level, individual commanders retained a substantial amount of autonomy in day-to-day affairs, often in the areas of tax collection, illegal logging and smuggling, but also in terms of more informal governance provision and interaction with civilians. These organisational structures enabled proliferation of localised patronage structures that were geographically demarcated and in which lower level combatants were incentivised by elevated social status and (small) material rewards. When peace came, as the central leadership was in exile, regional commanders were those who rose to prominence within the movement.

Hence, when a prominent elite divide occurred between different factions within GAM that also delayed the formal establishment of a GAM party, it was not over ideology or between supporters and opponents of the peace agreement. Rather, it was the manifestation of intra-group conflicts between regional rebel commanders who were worried about being side-lined from important spoils such as positions and peace dividends and the central leadership of the organisation that had lived in exile for the most part of the conflict.

\section{East Timor}

Fretilin proved unable to unify former resistance members and supporters to secure a coherent and unified party organisation. Instead, ex-combatant loyalties are divided amongst different factions of the resistance according to membership in the armed front (Falintil), the clandestine front, the Fretilin party or other leaders. Since it first mobilised for independence after the Indonesian occupation of East Timor in 1975, the resistance movement, Fretilin, evolved into a highly complex organisational structure. In contrast to the GAM leadership, who for the most part were unified in their ideological prescript for an independent Aceh, the East Timorese resistance had become increasingly fragmented over core issues such as the role of the armed wing and how to organise the resistance inside and outside of East Timor. The fragmentation into multiple fronts such as a split between Fretilin and its armed wing, Falintil; the formation of the National Council of Maubere Resistance (CNRM) by Falintil commander Xanana Gusmao; and the manifestation of highly autonomous urban clandestine movements have had direct influence on politics after independence. The fragmentation resulted in a lasting split between the founding leaders of the resistance movement.

The reliance on ideational incentives to mobilise members did not bind the organisation together. Instead, it has served to create lasting internal splits. Against the backdrop of a fragmented political landscape, unclear prospects for former resistance members and weak and confrontational leadership, former combatants and resistance members sought to influence politics via extra-legal interest groups. The most prominent of these ex-combatant associations that were created after the fallout over the establishment of the armed forces was the Council for the Popular Defence of the Democratic Republic of Timor-Leste (CPD-RDTL). The group mounted demonstrations against the Fretilin government, accusing the leadership of corruption and nepotism. Another group was the Sagrada Familia, led by former Falintil commander Elle Sete (alias L-7). Elle Sete had fallen out with several Falintil commanders including Xanana Gusmao. In April 2000, he had left the Falintil Aileu cantonment with some of his troops and their weapons to return to his birthplace in Baucau. Both groups drew their main support from disaffected ex-Falintil, but their membership base also included poor farmers and unemployed youth who had not been active during the war. The membership was concentrated in the birthplace of their leaders. 
The fact that ex-combatant mobilisation became much more confrontational in East Timor than in Aceh in part confirms theoretical expectations that members who were mobilised by ideational incentives have less tolerance for political compromises of ideas and values. The outcome of sustained mobilisation by ex-combatant groups established outside and without the organisational vehicle of the former rebel party has defined the political discourse of political parties and actors in East Timor.

\section{Colombia}

\section{Söderström, J. (2016). The resilient, the remobilized and the removed: party mobilization among former M19 combatants. Volume 18, Issue 2.} https://doi.org/10.1080/13698249.2016.1205565

The 19th of April Movement, or M-19, was a Colombian guerrilla organisation movement. After its demobilisation it became a political party, the M-19 Democratic Alliance (Alianza Democrática M19 ), or $A D / M-19$. The $M-19$ traced its origins to the allegedly fraudulent presidential elections of 19 April 1970.

Using life history interviews with former combatants of the armed group M19 in Colombia, this article demonstrates what aspects of the party mobilise and stymie their political mobilisation. Through exploring three typical political life paths - the Resilient, the Remobilised and the Removed - this article demonstrates the long-term challenges of post-war politics, the role of the party, as well as the personal journey from (war and) peace to democracy. Söderström suggests this typology can be useful in other cases, for both describing the paths taken among other armed groups, and explaining such variation.

This article examines how the new political party shaped the political mobilisation among individual ex-combatants, in the case of M19 in Colombia. Individual political mobilisation varied across the failed trajectory of M19 as a political party. The mobilisation of individual members is only partially dependent on the political reintegration of their armed group. Political mobilisation, while a dominant theme in their lives, was cyclical across their lifetime. The long-term perspective employed in this article is crucial to revealing these trends

This article underscores how conflict identities in general can remain intact over long periods of time, which can lead to either protracted armed conflict or discordant party politics. Importantly, other arenas of politics were open to former M19 combatants - they could continue within M19 ranks or move into other arenas of politics; in contexts where former combatants are shunned such reorientation is unlikely

Overall, the interviewed were very involved in politics, and expressed a strong attachment to both the M19 group and to politics. The development of the party post-disarmament was not irrelevant in conditioning their form of participation and for some it was even pivotal. Importantly, the perception of the group's agenda, and the leadership development within the party, as well as specific individuals' role for mobilisation, were evident in the interviews. The group was also important to the degree that it offered patronage and supported the continuation of the network. For some, these factors caused them to move away from the party created in the wake of M19's disarmament, and into other arenas of politics, for others these factors helped sustain their political engagement post-disarmament. For lower ranking combatants, the party and group was 
the main vehicle for their political mobilisation, and thus the failure of the group had severe repercussions at the individual level.

The centrality of the M19 identity to all the life paths explored in this study is striking. The legacy of experiencing armed combat within this group has shaped the political mobilisation of these individuals. For many the experience of armed combat and the political ideals developed during the conflict was a bigger determinant of their political mobilisation after disarmament than the trajectory of the party. Experiences of risk and nostalgia have also shaped the development of a political life post-disarmament and the continuation of their M19 identity. The experience of risk in the past created an ongoing cycle of having to justify past behaviour through continued political mobilisation. Feelings of nostalgia resonated more with those removed from politics postdisarmament. The M19 identity and legacy were felt throughout their life, and formed the basis for many of their life choices, and political choices. It seems partisanship (or armed group membership) is largely a question of a social identity for the individual member, even if the party itself does not exist in its original form. Despite the failure of the group as a party, ideological attachment and group identity remain strong among former M19 combatants, long after the end of the armed conflict. For some, M19 has been a factor in their life for 40 years. Thus, this article underscores the importance of taking the creation of a social identity into account when trying to explain the role played by political parties in the lives of its members.

\section{Palestine and Lebanon}

\section{Berti, B. (2016). Rebel politics and the state: between conflict and post-conflict, resistance and co-existence. Civil Wars, 18:2. https://doi.org/10.1080/13698249.2016.1205560}

The study draws on the cases of Hamas and Hezbollah, looking at patterns of engagement with the state through their grassroots activism, institutional politics and governance. Despite their distinct political discourses, structures, political strategies and status; both the Palestinian Hamas and the Lebanese Hezbollah are simultaneously sophisticated armed groups; political parties; as well as social organisations involved in administering and delivering social services and autonomous provision of governance. They are paradigmatic cases to illustrate the multi-layered and hybrid relationship non-state actors can develop with the state and its political institutions.

Liminality and in-betweenness define also their simultaneous investment in military, social and political activism whilst actively participating in conflict, in the process developing a political ideology, programme and discourse. The result of this investment is that both groups have over the years developed ad hoc political institutions, grassroots, institutional and governance activities and a self-standing political ideology.

\section{Palestine}

The Palestinian Hamas, or the 'Islamic Resistance Movement' (Harakat al Muqawama alIslamiyya), was established as the armed wing of the Gaza-branch of the Muslim Brotherhood at the outset of the First Intifada, in 1987. In the following decades, the group gradually evolved and expanded, going from being a relatively unsophisticated armed faction to becoming, especially in the past decade, the main militant group operating in the Palestinian arena. This evolution was mirrored by an even deeper political and social process of adaptation, with the group developing a political movement, a communication apparatus, an external armed wing and a political party. 
This process was also accompanied by the group investing in maintaining and then expanding the social services network it inherited from the its predecessor, the Muslim Brotherhood in Gaza and the social-charity institutions it had set up.

Hamas is formally organised as a bureaucratic hierarchy topped by the Shura Council as its main decision-making body and followed by a diaspora-based executive organ, the Political Bureau, as well as by smaller regional Shura councils and local cells. Operating under this umbrella, the group developed a diverse and specialised organisational structure with a relatively geographically dispersed and decentralised leadership and with ad hoc institutions to administer social and political activities. Decentralisation also led to considerable autonomy to be held by the group's political leaders. At the very minimum, Hamas has indeed four functionally distinguishable main centres of power: a political wing/party leadership located in Gaza; a military apparatus, also operating within the Strip; a diaspora-based political leadership; and, a social movement core. A West Bank-based leadership and a group of Hamas members held in Israeli custody can be added as additional subunits. As a result, Hamas's non-military activities are carried out through ad hoc sub-organisational institutions with a relative level of local autonomy.

Hamas became first involved in grassroots politics shortly after its establishment in the late 1980s, consistently and directly taking part in elections in universities, work places and trade unions. The decision to create a parallel institutional political party to take part in electoral politics was first discussed in the mid-1990s, following the Oslo Accords, the creation of the Palestinian Authority (PA) in 1994 and leading up to the 1996 Palestinian legislative elections. In parallel to its political activism, Hamas also developed its autonomous social services network expanding it from the mid-to-late 1990s through a bottom-up, grassroots approach by becoming involved in charity work, development and poverty alleviation programmes and by establishing neighbourhood-based organisations, thereby providing local embryonic structures of selfgovernance and community-based political representation.

After gaining de facto control and becoming the sole political authority within the Gaza Strip; Hamas insisted on creating a de jure and de facto separation between the reformed security sector in Gaza, operating under the authority of the Hamas government, and the group's armed wing, the Izz ad-Din al-Qassam Brigades. The policy of separation between institutional and insurgent forces reflected Hamas's desire to preserve the armed wing's operational autonomy and 'outsider' status.

In Gaza, the Hamas-led government invested in strengthening coordination and control of Islamist social organisations, including those that previously held an indirect relationship with Hamas, as a tool to boost its governance records and effective control. Similarly, the Hamas government has at times relied on the Qassam Brigades to support internal security operations, both to crack down on crime as well as on political opposition. But while the cooperation between Hamas's social apparatus its military wing and the political leadership ruling Gaza does occur; competition between the different centres of powers is not uncommon. For example, the parallel existence of the Qassam Brigades as an autonomous non-statutory armed group operating outside the realm of control of the Hamas government creates a de facto challenge to the government's sole control and authority of the Strip; one where Hamas as a rebel ruler shares its monopoly on the use of force with Hamas as a resistance/insurgent force. 


\section{Lebanon}

In the case of Hezbollah, Berti identifies a similar formalisation of non-military institutions; albeit with lesser autonomy, stronger mechanisms for internal control and coordination and an overall stricter hierarchy. Since its formal creation in 1982, Hezbollah evolved into a highly formalised organisation, headed by the Majlis al-Shura (Consultative Council) and led by Secretary General Hassan Nasrallah. Under this centralised decision-making body, the organisation has an intricate structure, including a subordinate executive apparatus - made up of an executive council, an advisory organ (the politburo), parliamentary, judicial and jihad councils - as well as a military wing, a media and communication system, a political party and a complex governance, charity and welfare network.

Hezbollah's political practices are also rooted in the simultaneous grassroots and institutional politics approach. Initially created as an armed movement in the context of the Lebanese civil war and catalysed into action by the 1982 Israeli military operations in Lebanon; Hezbollah later evolved into a multifaceted socio-political and military organisation, becoming simultaneously involved in grassroots and institutional politics as well as in delivering social services through an alternative welfare network. . Following the end of the Lebanese civil war and the ratification of the Taif Accord (1989) Hezbollah chose to embrace institutional politics and compete in the 1992 parliamentary elections. This decision was the result of a number of factors including the postcivil war shift of the political confrontation from the battlefield to the political arena, the desire to convert the supporters acquired through the group's 'resistance' against Israel into a political constituency and the beginning of Syria's 'tutelage' over Lebanon. Syrian military occupation and political dominance over Lebanon between 1989 and 2005 offered Hezbollah the possibility of joining a friendly political system, i.e., one in which Damascus directly ensured that Hezbollah would be able to participate in institutional politics without having to relinquish its military apparatus. Since 1992, Hezbollah - much like Hamas - also acquired a parallel role of 'insider institutional actor' and 'outsider resistance movement'.

After the 2005 Syrian withdrawal from Lebanon, Hezbollah's political activism further increased with the group agreeing to join the executive cabinet and assuming ministerial posts within the Lebanese political system. Yet, integration into the political system did not mean having to relinquish its extensive social services network, nor having to do without a parallel and independent armed-political movement, whose strategy and military actions were not under the formal or informal control of the Lebanese state.

In the case of Hezbollah, the group's relationship with the state varies from conflict, to competition, to cooperation and shared governance. As a military organisation, Hezbollah's autonomous armed wing does challenge in a fundamental way the state's monopoly on the use of force; yet the relationship between the group and the Lebanese Armed Forces should not be seen as necessarily antagonistic. Rather, there is a de facto compartmentalisation of roles; with occasional cooperation - as was the case with the coordinated operations against jihadist rebel factions, in 2007, or more recently along the Syrian-Lebanese border since 2014. As administrator of a widespread social services network and an autonomous provider of governance, Hezbollah's relationship with the state is similarly multi-layered. On the one hand, Hezbollah has established a sophisticated and comprehensive social services network in Shiitemajority areas within Lebanon - from Beirut's southern neighbourhoods and suburbs to the 
Beqaa Valley, to the south of the country - where the state had historically been conspicuous by its absence.

\title{
Mozambique and Angola
}

\author{
Leão, A. (2007). Different opportunities, different outcomes - Civil war and rebel groups in \\ Angola and Mozambique. Deutsches Institut für Entwicklungspolitik. \\ https://core.ac.uk/download/pdf/71734602.pdf
}

The author of this papers notes that Angola and Mozambique share a common colonial history that determined the nature of their independence: the lack of political space in Portuguese politics precluded a political solution for independence, which led to armed struggle. Both countries exchanged a single-party regime with a centralised economic policy for multi-party democracy and a market-led economy. Both movements were founded in the context of the Cold War geography on the basis of ethnic, social and economic grievances.

It is unlikely, however, that either could have progressed without the opportunities presented by the support they received from external actors; external pressure and interference was paramount in the way they developed, in the legitimacy they enjoyed or lacked and in the choices open to them. While UNITA (Angola) began with a clear political agenda, RENAMO's (Mozambique) initial agenda was entirely military. UNITA progressed from political party to warlordism; RENAMO developed from a warlord movement to a political opposition.

The natural endowment of each country was to play an important role in the decision-making processes of the two movements. Both UNITA and RENAMO pursued various strategies in the search for financial assistance and political legitimacy. For RENAMO's fighters the immediate gains from peace in the form of two years' salary proved to be more advantageous than a return to a foreseeably protracted conflict. UNITA's diamond wealth precluded any immediate gains from a peace agreement or any pledge the international community might make: the movement had more to gain from the conflict. Once that wealth started to dwindle, UNITA began to falter. Grievances alone were not able to sustain the continuing war. While RENAMO fighters had a vested interest in the Mozambican peace settlement, since it entailed a material gain for each of them, UNITA fighters benefited from the revenue generated by diamonds, which exceeded anything a peace agreement might bring. Once that revenue declined, UNITA suffered mass desertions, even though its leader continued to be committed to war.

It is none the less the natural endowments of the two countries that seem to have determined the leverage of the international community in the peace processes. Mozambique was and remains dependent on external aid. This enabled the international community to put pressure on its government, but also bound the international community to its commitments and gave donors a vested interest in the successful outcome of the peace process. Angola achieved peace by means of a perceived military victory, and the international community was not involved in the peace process. The leverage Angola enjoyed as a result of its mineral wealth reduced the leverage which the international community might otherwise have had, and international vested interests in Angola are eminently economic rather than humanitarian. 


\section{References}

Arjona, A. (2014). Wartime Institutions: A Research Agenda. Journal of Conflict Resolution. https://doi.org/10.1177\%2F0022002714547904

Börzel, T. (2010). Governance without a state: Can it work? Regulation \& Governance. Volume 4, Issue 2. https://doi.org/10.1111/j.1748-5991.2010.01076.x

Collier, P. et al. (2003). Breaking the Conflict Trap : Civil War and Development Policy. World Bank. https://openknowledge.worldbank.org/handle/10986/13938

Fortna, V. \& Huang, R. (2012). Democratization after Civil War: A Brush-Clearing Exercise. International Studies Quarterly 56 (4). https://dx.doi.org/10.2307/41804834

Harbom, L. et al. (2006). Armed Conflict and Peace Agreements. Journal of Peace Research, vol. 43, no. 5. https://doi.org/10.1177\%2F0022343306067613

Lyons, T. (2016). Victorious rebels and post-war politics. Civil Wars. Volume 18. https://doi.org/10.1080/13698249.2016.1205562

Lyons, T. (2016a). From victorious rebels to strong authoritarian parties: Prospects for postwar democratization. Democratization. Volume 23. https://doi.org/10.1080/13510347.2016.1168404

Sindre, G. \& Söderström, J. (2016). Understanding armed groups and party politics. Civil Wars. Volume 18. https://doi.org/10.1080/13698249.2016.1205559

Söderberg Kovacs, M. \& Svensson, I. (2012). The Return of Victories? The Growing Trend of Militancy in Ending Armed Conflicts. Conference paper.

https://paperzz.com/doc/7794997/the-growing-trend-of-militancy-in-ending-armed-conflicts

Staniland, P. (2012). States, Insurgents, and Wartime Political Orders. Perspectives on Politics. Vol. 10, No. 2. https://www.jstor.org/stable/41479550

Toft, M. (2010). Ending Civil Wars: A Case for Rebel Victory? International Security. 34 (4). https://doi.org/10.1162/isec.2010.34.4.7

Weinstein, J. (2007). Inside Rebellion: The Politics of Insurgent Violence. Cambridge, UK: Cambridge University Press

\section{Suggested citation}

Avis, W. (2021). Armed group transition from rebel to government. K4D Helpdesk Report No. 1056. Institute of Development Studies. DOI: 10.19088/K4D.2021.125

\section{About this report}

This report is based on six days of desk-based research. The K4D research helpdesk provides rapid syntheses of a selection of recent relevant literature and international expert thinking in response to specific questions relating to international development. For any enquiries, contact helpdesk@k4d.info.

K4D services are provided by a consortium of leading organisations working in international development, led by the Institute of Development Studies (IDS), with the Education Development Trust, Itad, University of Leeds Nuffield Centre for International Health and Development, Liverpool School of Tropical Medicine (LSTM), University of Birmingham International Development Department (IDD) and the University of Manchester Humanitarian and Conflict Response Institute (HCRI). 
This report was prepared for the UK Government's Foreign, Commonwealth \& Development Office (FCDO) and its partners in support of pro-poor programmes. Except where otherwise stated, it is licensed for non-commercial purposes under the terms of the Open Government Licence v3.0. K4D cannot be held responsible for errors or any consequences arising from the use of information contained in this report. Any views and opinions expressed do not necessarily reflect those of FCDO, K4D or any other contributing organisation.

(C) Crown copyright 2021.

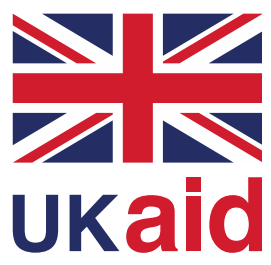

from the British people 